\title{
Chapter Twelve: \\ Conflicting Readings: The Cartoon Crisis seen from Pakistan
}

\author{
Elisabeth Eide
}

A view of ourselves as disconnected - as absolved from the obligation to know the "other" - is, given the nature of a system, to occidentalize by misinterpreting who we are, including the effects we have in the world.

Deborah Gewertz and Frederick Errington $(1991,84)$

Occidentalism seems poised to become the dominant discourse of the future. This means that attempts to theorise, understand and do something about it will become more common - and more necessary.

Ziauddin Sardar, 2004

The caricature controversy became a world issue which gave the Samuel Huntington phrase "Clash of Civilizations" extended attention in Pakistan, where one popular view was to see the caricatures as part of a Western conspiracy against the Muslim world. On the other hand, the leading Pakistani newspapers were significantly less unified in their approach than one might imagine from Europe. ${ }^{1}$ The Pakistani background is complex. My ambition here is not to venture into fully-fledged explanations of the way in which the controversy happened, but to present a study of the press coverage in a country in which reactions to the caricatures of the Prophet Mohammed were particularly strong.

\section{A young nation}

Pakistan won its independence on 14 August 1947 after a controversial and bitter struggle prior to the partition of India. The country was initially - contrary to popular belief - not to be "based on Islam", but would serve as a "home to Muslims", the largest religious minority in Hindu-dominated India. The founding father of Pakistan, Mohammad Ali Jinnah, was a secular-oriented president. After his death in 1948 followed both military and democratically elected rulers who gradually tended to be more lenient towards religious parties, and from 1956 Pakistan was constitutionally an Islamic state. The president at the time of the crisis, General Pervez Musharraf, had ruled the country since his military coup d'état in 1999, launching his slogan "enlightened moderation", which may rhetorically be interpreted as a wish not to follow the path of leniency toward extremism.

1 This researcher became a special observer during a stay as a post-doctoral researcher at The University of the Punjab, Lahore. I landed in Pakistan just when the "cartoon crisis" broke out and stayed for almost half a year. I also have previous experience from Pakistan from 1987-1988. 
Since its foundation, Pakistan has harboured a rather secular-oriented middle class. Simultaneously various religious parties have wanted the state to put more emphasis on Islam in the running of the country's affairs by fully implementing the Shari'a. ${ }^{2}$ These parties experienced an upsurge of influence during the Afghanistan war (1979-), particularly in the period of Soviet occupation (1979-1989). This was due to their alignment with the more fundamentalist parts of the Afghan resistance to the Soviet occupants and (in some cases) the military dictator Zia ul-Haq's sponsoring of these (supported by the U.S. via ISI - Pakistani secret intelligence). The Soviets' attempts at modernization and secularization of Afghan society through military means; occupation and coercive violence were met with a growth in fundamentalist movements, but traditionalists ${ }^{3}$ also gained political ground.

The war in Afghanistan has not come to an end, and the post 9-11 US invasion of the country has implied a growing opposition to Western states, in particular to the US, among the general public of Pakistan. Although President Musharraf was considered a close ally to President Bush in the global "war on terror", there were pockets in Pakistan where Taliban leaders seemingly move freely, implementing their codes of behaviour and recruiting a growing number of young men for the "jihad" against the US-led "Enduring Freedom" (and other foreign troops) and the present leaders in Kabul.

Although probably only a minority of people in Pakistan would want to side with Taliban, a degree of sympathy for them and other opposition to the Kabul leaders is rather widespread, as is the scepticism towards "the West" and what is considered its double standards. ${ }^{4}$ A long-lasting critique of 'Western lifestyle', exposing what is widely considered as "against Islam" is another feature of parts of the press; thus (directly or more subtly) recommending a more religiously "pure" lifestyle. This scepticism may have been somewhat modified in some circles due to the upsurge in terrorist activities in Pakistan, leaving several hundred civilians dead, in 2008-2009; 2010 started with yet another attack, killing 93 in North Wester Frontier Province. Simultaneously the majority of the media and journalists would in 2006 warn against the "street power" of the "religious parties" 5 and their exploitation of controversies for their own political benefits. On the other hand, the media in controversies where Islam is threatened may tend to gravitate toward a "centre" of consensus which to a certain extent may benefit the same parties.

2 Jamaat-Islami (JI) and Jamiate Ulema Islami (JUI), part of the political coalition MMA.

3 I interpret fundamentalist as a movement emphasising the application of the Qur'an literally and strictly while opposing more liberal approaches. Traditionalism is considered as a direction blending fundamentalism with the local traditions of a given society - Taliban in Afghanistan may serve as an example of the latter, while the distinctions between the two are not always crystal clear.

4 Regarding human rights; Guantanamo and Abu Ghraib are frequently mentioned in Pakistani papers, as was also the Western non-acceptance of elected Hamas and previously the Algerian FIS.

5 "Street power" is a concept used by many Pakistani observers to describe the influence of parties like JI and JUI, while also emphasising that they do more poorly in national elections. 
Pakistan has a considerable number of Urdu dailies and publications in regional/local languages (Punabi, Sindhi, Gujrati, Pushto), as well as 13 English language dailies largely catering to the educated elite of the country. The total number of publications considered to be nationwide is 173 (Orient Blue Book 2005). A commonly held view is that the English newspapers tend to be more liberal than the other press, partly due to their elite readership. ${ }^{6}$ Their net publications probably reach much further than to the "paper audience" and are often read among the Diasporas living in Europe, North America and the Gulf States.

The laws in Pakistan have been gradually modified due to pressure from religious parties to become more in line with the Islamic Shari'a law, and this has lead to a situation in which freedom of expression is more limited than when the state came into being.

As may be seen below, the present constitution of Pakistan implies important restrictions on the freedom of expression.

Every citizen shall have the right to freedom of speech and expression, and there shall be freedom of the press, subject to any reasonable restriction imposed by law in the interest of the glory of Islam or the integrity, security or defence of Pakistan or any part thereof, friendly relations with foreign states, public order, decency or morality, or in relation to contempt of court or commission of or incitement to an offence. ${ }^{7}$

This article leaves much to interpretation, and may be used to severely limit freedom of expression if applied literally. By the constitution, blasphemy is considered one of the most serious crimes, in contrast to most European countries, and this has been used to attack religious minorities ${ }^{8}$ In May 2005 Reporters Without Borders (RSF) published a list of 34 countries whose governments directly curbed Press freedoms, and there Pakistan was named alongside Iran, China, Bangladesh and Cuba, and in 2009 Pakistan was ranked number 159 on their Press Freedom Index for 2009, with Afghanistan number 149 and Saudi Arabia 163. This may seem partly unjust, since the multitude of press is very different from some of these states - and since the press, even under the country's various dictatorships (the last one ending with the elections in 2008), has been able to voice a fair amount of harsh critique of leaders and powerful institutions.

6 On the whole, the newspaper readership is small, due to large illiteracy (appr. $50 \%$, UNESCO) and poverty.

7 Article 19 in the Pakistani constitution. In contrast, see for instance Article 19 in the UN Universal Declaration of Human Rights: "Everyone has the right to freedom of opinion and expression; this right includes the freedom to hold opinions without interference and to seek, receive and impart information and ideas through any media and regardless of frontiers.".

8 One example of alleged blasphemy happened in 2005, when Mr Ashiq Nabi from Nowshera was charged with blasphemy after, during a quarrel with his wife, was accused of hurling a copy of the Quran to the floor. The wife was the only witness, Nabi afterwards asked forgiveness, but a local cleric issued a fatwa, thus igniting local violence, and subsequently Nabi was killed by a mob of villagers (HRCP 2005.). 
The amount of coverage of the cartoon issue in the Pakistani press was impressive. In this study it has been necessary to limit the scope mainly to the editorials and comments of six important papers, with special emphasis on the representation of "Freedom of expression" and representations of the "West". Two prestigious monthlies and their comments are included to demonstrate the variety of views. In addition, some emphasis will be put on the first days of news coverage, concentrating on the two largest English language dailies, The News and The Dawn..$^{9}$ For an overview of the publications, see appendix 1 .

The examination of the editorial material has been inspired by the methodology of Critical Discourse Analysis (CDA), viewing editorials and comments as an important contribution to (and part of) discourses in the Pakistani public sphere and society, and thereby also as social practice and power relations. A model of analysis starts from the linguistic level, then considers the genre (here: editorials and comments) and finally the institutional-professional framework, thus finally aiming at understanding the editorials and their positioning in Pakistani society at-large (Fairclough 1995, Bhatia 1999, Eide 2002, 2006). Additionally, I will treat journalism as a 'field' of its own with a relative albeit weak autonomy (Bourdieu 1998, Benson \& Neveu 2005), a field influenced by other fields, particularly the economic and the political fields. In Pakistan the religious field may be considered either as an important part of the political field, or as a field of its own, due to the important role played by religion in the country's affairs. Since religion seems to be exploited by various politicians in their contest for power, the former seems more feasible.

\section{Orientalism and Occidentalism}

The cartoon issue may be studied from various angles and perspectives. One perspective is the tradition of the Orientalism critique - and its presumed adversary Occidentalism (Said 1978, 1981, 1994, Carrier 1995, Buruma \& Margalit 2005). The problem with both terms is that they are applied in several ways. While the world has become familiar with Said's way of interpreting Orientalism, anthropologist James Carrier is said to have coined the term Occidentalism. By emphasising the dialectics between Orient and Occident, he claims that when defining what the Orient is like, Western anthropologists and other researchers define it in relation to something else, "habitually the environment in which they are situated. The Orient only took meaning in the context of another term, 'the West', and in the process (also) the West was subject to "essentializing simplifications" (Carrier 1995, 3).

9 Due to time and resources, it was difficult to obtain access to more than translated versions of a selection of editorials and comments from the main Urdu papers. In this respect I owe my gratitude to assistant Beenish Cheema, then part-time lecturer at Punjab University. 
According to Carrier, another brand of Occidentalism occurs "in studies of the ways that people outside the West imagine themselves, for their self-image often develops in contrast to their stylized image of the West" (Carrier 1995, 6). The latter approach may however be less influential at the global level, where the Orientalist tradition is still considered strong, but at times maybe more influential on a local scale, due to the fact that it may be less challenged academically. ${ }^{10}$ Adding Carrier's to Said's critique $(1978,1981,1994)$, one may assume that simplified stereotypes travel both ways. But as Carrier mentions: "In this larger, inter-social arena, Westerners have been more powerful and hence better able than people elsewhere to construct and impose images of alien societies as they see fit" (Carrier 1995, 10).

Thus, the question of whose definition will be influential on an international scale may be viewed as linked to the nature of the prevailing hegemony. It is important to keep in mind that 'the West' constructed in studies of 'the East' may be a tacitly presupposed version of (a prototype of) the white, middle-class male U.S. Westerner, more than the "real" West, which harbours a diversity not taken into account in processes of simplification. And assuming the existence of such a West (when situated 'outside'), the images constructed of the 'we/they' gap may be perceived as larger than reality, leading to polarization.

Another interpretation of Occidentalism has been presented with Ian Buruma and Avishai Margalit (2004), as:

...the expression of bitter resentment toward an offensive display of superiority by the West, based on the alleged superiority of reason. More corrosive even than military imperialism is the imperialism of the mind imposed by spreading the Western belief in scientism, the faith in science as the only way to gain knowledge (Buruma and Margalit 2004, 95)

The four most important elements of Occidentalism mentioned by Buruma and Margalit are hostility to the city, revulsion for the material life, abhorrence of the western mind and hatred of the infidel.

In short, the two writers define Occidentalism as the "dehumanizing picture of the West painted by its enemies" (op.cit.: 5). But when trying to clarify the term, they seem to exclude various other ways in which Othering of the west may take place, for example in the non-western media. This definition also seems less subtle in its suggestion of relations between representation and hegemony than the Orientalism critique. Buruma claims that wherever it occurs, Occidentalism is fed by a sense of humiliation or defeat (Buruma and Margalit 2004). While it is easy to recognise these factors, a question remains: May one not assume Occidentalist "counter-discursive" expressions, at times being fed by a feeling of superiority towards an imagined West and thus harbouring other than the ingredients mentioned above?

Ziauddin Sardar writes that Occidentalism, as constructed by Buruma and Margalit, "cannot be equated with Orientalism", since Orientalism has a very long history and "is a discourse - a coherent structure of knowledge through which the west has un-

10 The traditional Orientalism (as discipline, studies of the East, and as literature) has been subject to critique for decades - as has Said's critique by several scholars (Lewis, Al-Azm, Berg etc.). 
derstood and represented the "Orient" and through which the west produces self-confirming accounts of the non-west (Sardar 2004). Sardar also questions Buruma \& Margalit's Occidentalism as "hatred of the western material life", and suggests that the hate may have more to do with the state ov poverty prevailing in the former colonies (op.cit.).

For this endeavour a broader approach seems more feasible, in which Occidentalism may be carefully interpreted as counter-discursive expressions of sorts, essentialising and simplifying "the West" as Other. This often takes place in a process often of equally simplifying self-definitions, and often from a defensive position or or "defeat and humiliation", but also at times from a position of ambition and rejection. Thus, an important question is whether the cartoon controversy led to an upsurge in essentialist and crude representations of an imagined "West" in Pakistani media, or whether a more differentiated coverage may be found. Do Pakistani media reject freedom of expression, thus demonstrating their difference from a presumed Western liberalism when it comes to certain religious issues? Or, do the interpretations of fundamental freedoms just differ to a degree from many views also found in Western countries? One hypothesis from the materials would be that the more elitist the publication, the more liberal and 'understanding' when it comes to pluralist perspectives on the cartoon issue.

\section{The early news coverage}

As the news coverage of the issue in Pakistani newspapers was massive, this analysis will concentrate on news items only from a few early days of February, after the first demonstrations broke out. ${ }^{11}$

In The News a front page article carried the headline "Worldwide protests against blasphemous cartoons: Passions inflamed in Muslim world" (3. February.2006), thus from the early phase indicating the global character of the issue and the presupposed unified reactions of the Muslim Ummah. This news report carries stories from Gaza, from Paris and from two cities in Pakistan where early rallies took place (Lahore and Multan). It is illustrated by a picture from Gaza, in which two activists point their machine guns at a signboard of the European Commission. The paper also cites the Danish Foreign Minister and foresees more anger after the Friday prayers which were to take place on the same day.

The concept "blasphemous cartoons" was to be one of the main denominators for the Jyllands-Posten caricatures throughout much coverage in Pakistan - both in news, editorials and comments. In this early phase the most important demand of the demonstrators seems to have been an apology from the Danish government - and, addressing the Pakistani government - a call for severing of diplomatic and trade ties with Denmark, France and Norway. Speakers simultaneously condemned the "apathy of Muslim

11 It has been difficult to gather complete material, due to problems with archive systems and access to these, therefore this chapter does not carry a comprehensive quantitative analysis. 
rulers towards the attack on the most sacred personality" (op.cit.). The News cites a religious leader from Multan stating that "It is no justification that press is free" (op.cit.). On the other hand, The News also quotes both the apology of France Soir's owner - and the French paper's editorial, the latter defending the publication. Furthermore it refers to the Muslims in Denmark as being not satisfied with an apology from Jyllands-Posten, but simultaneously the paper is also calling for less harsh reactions from the rest of the Muslim world.

The other articles in the same issue are shorter, and when illustrated they show angry, shouting men with banners and/or raised fists. There were many more of these to come in the following weeks, but all were not showing aggression. ${ }^{12}$ Already the next day several papers - among them both The Dawn and The News - report about official Pakistani reactions to the publication. The Senate, the National Assembly, Province Assemblies and President Musharraf all condemned the cartoons, and the parliament called for government action. Musharraf is quoted as saying that "such acts would encourage those who speak of clash of civilizations. [...] "They have inflamed our sentiments and in the strongest terms I condemn it. [...] Any educated person who has any understanding of the situation around the world would not like to hurt the sentiments of the Muslims," the president said." (Dawn 4. February 2006)

The reactions from the assemblies were cautious, calling for diplomatic protests and summoning ambassadors, but no boycott was mentioned. On the same day, Dawn reported from a large demonstration in Karachi, under the headline: "Govt asked to withdraw envoys from EU states" (4. February 2006), under a photo of enraged men. These photos, often found in the European press, are typical for coverage also in Pakistan, but supposedly do not carry the same, negative connotation in a Pakistani audience, where the anger is more understood, even supported, at least as long as the demonstrations do not cause any damage.

All in all, the first news coverage may be summarised in three categories: the representation of national official reactions; government, parliament, or provincial level institutions,${ }^{13}$ all moderately angered); the representation of national "street reactions", i.e. demonstrations in various Pakistani cities (more aggressive); and of international reactions, both on the street and in higher circles. The coverage faithfully referred the reactions from both above and below, while the illustrations tended to deal with the "street reactions", both at home and abroad. It remained rather loyal to the political elite and establishment, and the cartoon issue seems widely regarded as uniting the nation.

12 Some were of female demonstrators, some veiled and even more unveiled, while still others showed people in specific peaceful positions (lying down) signalling sadness.

13 Already on 5 February, the Foreign Office in Pakistan summoned nine diplomatic envoys over the cartoon issue: France, Germany, Italy, Spain, Switzerland, Holland, Hungary, Norway and the Czech Republic; Danish envoys having been summoned before. The note to the various missions is harsh: "Such irresponsible acts would seriously jeopardize our common endeavours for enhancing understanding and cooperation between cultures and encourage sinister agendas for clash of civilizations." (Dawn 5. February 2006.). 
It is a feature of much early coverage that the Pakistani press - referring to the public opinion (some exceptions may be seen below) - does not seem to differ between the Danish (or Norwegian or other) state and the press. This may be linked to historical experience: in Pakistan as well as many other countries one is used to the state having much of a say when it comes to media content.

\section{Phases: From anger to worry and reflexivity}

In the following, some texts, mainly editorials, are selected for special scrutiny, and others grouped around them as comments to such "mainstream opinions" reflecting the political thinking of the various publications and opinionated intellectuals. The coverage of the cartoon issue in Pakistan - now focussing on editorials and columns - may be divided into three phases.

\section{Phase 1: The Discourse of Disgust (Feb 1-14)}

The initial reactions also in the editorials were communicating anger and condemnation of the European publishers, accompanied by reflections around the concept of freedom of expression and its limits. An undercurrent warned against exceeded and violent reactions; other undercurrents (some columnists) advocated punishment for the publishers and cartoonists as well as trade boycott of the countries in which the cartoons were published. Several comments suggested that the caricatures were part of a larger Western conspiracy against the Muslim world.

The traditionally liberal and prestigious English newspaper Dawn in its initial reaction had a harsh tone in characterising the caricatures: they are "offensive [...] blasphemous material", also labelled as "the warped output of some cartoonist's weird imagination" (Dawn, editorial, 4. February 2006). The sincerity of the Danish and other publishers is doubted: "This is supposed to be an assertion of press freedom on the part of these newspapers" (e.a.) Furthermore the editorial appeals to tradition:

There is an old conundrum about where one person's freedom ends, and the other's begins. In the subcontinent, with its multiplicity of religions and beliefs, newspapers (as indeed the broad mass of the people) have learnt to respect religious and ethnic sensibilities and do not confuse freedom of expression with freedom to ridicule a religion or a religious figure. The media here believes that, with its reach, it has a special responsibility in this regard as opposed to political groups or individual writers, etc., who can say or write what they want to. The "Christian West" and "Jewish Israel" are often referred to in derogatory terms in the political discourse in the Muslim world, but none of the revered figures in the two religions are ridiculed or caricatured because they are all equally revered by Muslims (op.cit.).

Interestingly, this editorial does not refer to Pakistan, but to the entire subcontinent (at least including the original India, with Bangladesh) and lauds the press for its sensibility. This lauding may be interpreted as a euphemism, considering past communal 
conflicts and mutual accusations of terrorist acts ("foreign hands" involved), especially seen in Indo-Pak relations.

The unity of the three religions is emphasised by mentioning the fact that prophets in Judaism and Christianity are also sacred to Muslims. Interestingly, this text also reflects critically on discourses of the Muslim world and their derogatory ways. Furthermore, the way Dawn underlines the special responsibility of the media-as opposed to politicians and others who "can say and write what they want to"-may be interpreted in two ways, both as giving the media a status as the nation's consciousness, and on the other hand an euphemism for the actual situation for freedom of expression in Pakistan. ${ }^{14}$

This unity finds an echo in Nawa-e-Waqt who also describes the caricatures as blasphemous, hurtful, shameless and undignified - thus demonstrating a discourse of disgust. The editorial sees the publication as part of a larger strategy:

Freedom of expression does not imply freedom from morals, values and regulations but stands for the protection and respect of religious and social values. [...] Every enlightened Jew and Christian scholar and journalist is well aware of Muslims' sentiments and beliefs regarding Prophet Mohammad (PBUH) ${ }^{15}$ In this context the publication of cartoons and their defence on the pretext of freedom of expression appears to be a well thought out strategy. (Nawa-e-Waqt 8. February 2006)

What this Urdu newspaper adds here, is the discourse of conspiracy. They suggest that the cartoons were meant to provoke, and the headline repeating Huntington's title underlines the we/them-theme of the text.

Already from the start Dawn found it necessary to warn against exaggerated reactions. Another factor which is underlined in many comments as well is the reference to Diaspora:

The media in Europe has perhaps yet to become accustomed to the large and growing Muslim presence on the continent and finds it even more difficult to be understanding of Muslim beliefs in the current confusion about Islam and terrorism. The right to blasphemy is not one of the rights of the press, however free it may consider itself to be, and the extensive reproduction of blasphemous material cannot be seen as anything but a deliberate affront. (Dawn, 4. February 2006, e.a.)

With the expression "deliberate affront", Dawn joins the conspiracy discourse, but otherwise it tries to balance its approach with the discourse of freedom under responsibility, which is frequently seen also in various opinion pieces.

The editorial hopes that "a greater sense of responsibility will gradually evolve" toward the religious sentiments "of the many communities in Europe". Thus this editor from Karachi offers advice to his colleagues in the West about responsible journalism, the whole editorial contrasting the sensibility of the "eastern" media to the "western" ones seemingly lagging behind ("has perhaps yet to ...") and in need of adjustment to

14 The News carried a small item about a college teacher who defended the cartoons in class, and subsequently was sacked from his position, having to leave the same day.

15 PBUH means "Peace be upon him", very often added when mentioning the Prophet Mohammad. 
modern-day development as well as a better understanding of the responsibilities of the press. Between the lines one may read an essentialisation of the sensible we as opposed to the irresponsible they ("media in Europe"), not taking into consideration the various practices of the latter or diverging views on Free Expression. A reversed development discourse may be seen; here the western media are taken to task and asked to adjust themselves to modern-day development, a world of migration and Diaspora. The editorial reflects on and tries to understand the sentiments of the people, showing more knowledge of the western media than the 'common man':16

On the part of the Muslim countries, most of them are used to a controlled media and whenever something gets written in the western press about Islam, they think that the government of the country concerned is somehow complicit. This leads to governments getting involved, as the authorities in Syria, Libya and Saudi Arabia have done. If there is a moral to be drawn from the present episode, condemnable as it is, it is that we must all respect each other's religious sensitivities and be more tolerant of each other's views. (op.cit.)

Furthermore, the editorial appeals to tolerance and warns against "violent action". A few days later The News also warns against violence in an editorial commemorating the martyrs of Karbala, ${ }^{17}$ and advocates that Muslims should "learn from history" and "follow the original message of Islam that has been distorted by our enemies as well as those from within who besmirch the good name of this great faith through acts of demagoguery and senseless violence", thus joining the ranks of the moderates (The News, 9. February 2006).

Two regular columnists in Jang strongly condemn the caricatures. M. Tufail raises the question of whether the European media have used freedom of expression as a pretext to insult other prophets or religious leaders: "Legally freedom of expression does not permit anyone to hurt the feelings or violate human rights, but why were such restrictions not placed on the media in relation to 140 crore $^{18}$ Muslims?" Tufail also underlines what he perceives at the double standards of the west and asks whether this kind of freedom of expression is equivalent to terrorism, or provocation of violence... (Jang, 07. February 2006). Syed Anwar Qidwai laments the fact that ...

Muslims all over the world are protesting over the blasphemous cartoons but neither Europe nor UN has taken any positive steps in relation to such sacrilege or to stop the publication of cartoons. [...] Democracy ensures the right of religious freedom, such religious freedom is also included in the charter of the UN. Why, then in the presence of such articles are the Muslims being insulted on the pretext of freedom of expression and freedom of the press. [...] Cartoons are a blow to

16 As it were, I got used to lines like "Norway printed the blasphemous cartoons" from men in the street and from students as well as some academics, although in Norway most people had barely heard about the small periodical Magazinet that printed the twelve cartoons.

17 This battle took part in year 680 in Karbala, present-day Iraq, between relatives of the Prophet Mohammad, particularly his grandson Hussain bin Ali - against the Umayyad Kalif Yazid I, who had several thousand men against Ali's less than hundred, who were surrounded and starved before they were slaughtered.

18 One crore $=10$ million, i.e. the number suggested is 1400 million Muslims. Other estimates are lower. 
interreligious dialogue and the cartoonists should be punished to set an example for others" (Jang 11. February 2006).

Qidwai both underlines the need for dialogue and asks for punishment to avoid further insults. This may indicate a lack of willingness to see the world from the European side and may be seen as mirroring a similar kind of unwillingess on the part of the newspapers in Europe publishing the cartoons: lacking the sensitivity to imagine the magnitude of the insult or its consequences for the ongoing interreligious dialogue. Jang's columnist seems to posit freedom of religion above freedom of expression, the latter a potential threat to the former.

Daily Times appeals to European editors asking them to consider cultural sensitivity, while first referring to the printing of "a cartoon strip" and the protests that followed. The editorial also mentions Reporters without Borders and their support to the ones who decided to publish the cartoons.

... saying that the reaction in the Arab world "betrays a lack of understanding "of press freedom as "an essential accomplishment of democracy". None of this has served the cause of bridging the gap between the Muslim world and the West, already torn by a growing chasm since the events of September 11, 2001. (The Daily Times, 4. February 2006)

This editorial places the responsibility for the increased gap on the shoulders of what it sees as irresponsible Western press leaders by combining printing of the caricatures with references to armed groups' threats and unrest in several Arab countries. Furthermore the editorial points at European secularism and double standards and thereby advocates a more complicated approach to freedom of expression:

The decision to publish the cartoons is indefensible and the employment of freedom-of-expression
argument is the worst excuse that can be used to justify it. Let's consider.
Europe has evolved along a certain trajectory that has seen the influence of religion wane to the
point of becoming non-existent. There is a general acceptance that Christianity can be caricatured
even though Christian groups that still put some premium on religion continue to protest such
acts. However, even as religion has been displaced, in its place we have theologies like the French
Jacobin secularism and political correctness. [...] The French decision to not allow freedom of
religion is one manifestation of it; the use of language in a certain way and the non-acceptance
of certain categories of social behaviour are others. This shows that the issue of freedom of ex-
pression is more complex than the way the European newspapers printing the highly offending
cartoons have posited. (ibid)

The metaphor "Jacobin" secularism may be meant to provoke negative sentiments, since the Jacobins were held responsible for the harsh second phase of the French revolution in which there was little tolerance for deviant views and consequently killing of many innocents. In other (more modern) terms; how can the French, who do not allow hijab in their schools, raise the banner of freedom? "Political correctness" is equalled with fundamental secularism. Between the lines one may read an analysis of political trends in line with Tariq Ali's and Johan Galtung's suggestions of what really is at stake: a "Clash of Fundamentalisms", not civilizations (Ali 2002, Galtung 2002).

The editorial also quotes a phrase which is found elsewhere in the press material from Pakistan: "The reason [for the Muslim reaction to the caricatures] is simple: the 
limit of one's freedom to punch ends where the other person's nose begins." This view, popular among Pakistani writers, may be interpreted as being in line with the warnings against hate speech and propaganda found in the UN charter and also in the constitutions of many countries as they looked in 2006. Or the appeal to always stop where another person's nose begins may if interpreted more rigidly, lead to a brutal curb on critique against religious practices and standards; which would seriously encourage both censorship and self-censorship. The editorial invites a dialogue though, and warns against violent actions:
What the European newspapers have done is deliberate and aimed at provocation. If there were a violent Muslim reaction to this insult, it would only feed into the current atmosphere of hate and the feeling of resentment and that is definitely not in league with efforts at bridging differ- ences. If Europe really wants a dialogue with the Muslim world, it must begin by understanding the sentiments of Muslims and how much the Muslims revere their religion and the Prophet (PBUH). Real understanding comes with respecting others, not denigrating them.
This is where Europe has fallen short. The governments and the peoples of Europe should begin to appreciate the world they live in. Not long ago the Europeans fought each other on the basis of sects and religions. It was because religion played a very important role in their lives. It still does in the lives of some people (Ibid).

Here, the concept of "development" is conceived differently from the Dawn editorial: Europe has abandoned religion, while in Pakistan it "still" lingers on. What Europeans did in history, Muslims and others on the subcontinent still practise. Stuart Hall quotes Roberts, stating that "Modern history can be defined as the approach march to the age dominated by the West" (Hall 1992, 278). The editorial may be said to refer - and maybe ironically so - to the traditional linear development discourse, well known from other press history (see for example Eide \& Simonsen 2008).

The difference (in level of this approach) is also emphasised by positing an incommensurable binary: Muslims versus Europeans, underlining the secularisation of Europe, and the "still" not so secular Muslim world. Another aspect of the above is a suggestion that the caricatures represented a repetition of the conspiracy discourse ("deliberate"), and a third, the way the editorial puts "governments and people" (presumably also media) of Europe in one basket, unlike Dawn, emphasising the independence of European media from their governments.In one specific article in the News journalist Shahina Maqbool interviews several Pakistani cartoonists "on blasphemous sketching". ${ }^{19}$ They unanimously condemn the caricatures, with very strong statements indeed ("third rate", "bigoted approach", "bad-taste cartoons", "planted by some wicked person", "huge injustice", "extremely immature and sadistic sense of humour based on ignorance and hatred", "a mischief of the Zionists", "the extremist approach of the Western media"). Javed Iqbal from Jang reflects upon the situation and tries to explore the differences between societies:

Every cartoonist has to follow a code of ethics. I, for one, would never discuss religion. Cartoons on sex and religion are prohibited in our culture. In the west, however, their best cartoons are on

19 This is not part of the editorials or columns, but a special case, where the Pakistani cartoonists speak, thus of great importance. 
these two subjects. [...] On the one hand, they [Westerners] call us fanatics, and on the other, they themselves have inflamed the sentiments of the Muslims. No matter how modern we are, no Muslim can tolerate an attack on his religion and on Prophet Mohammad (PBUH). (The News 9. February.2006) ${ }^{20}$

His conclusion is rather optimistic, since he is "sure they will not repeat this in the future". Others ask Westerners to do some rethinking when it comes to freedom of expression and express their concern at the "widening gulf between the West and the Muslim world".

One of the regular columnists of The News, Shireen M. Mazari, ${ }^{21}$ investigated the texts of the French and Norwegian constitutions on freedom of expression and defamation. She also quoted the European Convention for the Protection of Human Rights and Fundamental Freedoms. Her aim was to demonstrate that the political authorities in Europe could have taken action, and "sued the paper [Jyllands-Posten or others] for breaking the law of the land". She demonstrated that the paragraphs concerning freedom of the press in Europe are not without reservations that may be used legally.

So let us be clear about this so-called "freedom of expression" and the claimed legal helplessness of the European governments to take action against the papers printing the offensive cartoons. All this is absolute rubbish and this is where Muslims can take on the guilty in a non-violent and legal manner. (Shireen M. Mazari, The News 8 February 2006)

By not being simultaneously aware of the dormant character of paragraphs concerning blasphemy or defamation,22 Mazari treated the case as a "straight legal issue": The laws should be respected. She ended her column by stating that violence always backfires, and thus echoed the warnings from several other voices in the press. It did not help much.

\section{Phase 2: Street Rage and Self-flagellation (Feb 15-22)}

This short period may be labelled "The horror". Five persons in Pakistan were killed, mainly after some demonstrators in Lahore and Peshawar "went wild" and started burning down what seemed like Western property. ${ }^{23}$ The press demonstrated its selfflagellating abilities by turning emphasis more inward, towards the unruly elements destroying Pakistani lives and property and the authorities not preventing them from doing so. Important arguments put forward were how the misbehaviour might hurt

20 It should be mentioned - from a generic perspective that the journalist in this case starts the enquete with a rather strong condemnation of the caricatures; in other words a rather hybrid genre is at play here.

21 She is Director General of the Institute of Strategic Studies in Islamabad.

22 The Norwegian paragraph on blasphemy was last applied in 1933.

23 This might often be symbols of the West, like Junk food cafés, Telenor signboards, and Pakistaniowned houses partly leased by Western companies, but also ordinary Pakistani trucks, banks and cars were destroyed and burned, and looting took place demonstrating how criminal elements saw their opportunity. 
Pakistan's international reputation - and also make life more difficult for people belonging to the Pakistani Diaspora. Much blame was also directed at the Islamist leaders and organisers of some rallies. On the other hand, the anger was still kept up by both editorials and comments - blaming Jyllands-Posten for having incited this controversy.

After two days of violent demonstrations Karachi-based Dawn accused the authorities of not preventing the riots, challenging the chief minister of Punjab in particular. Thanks to the unruly elements, the initial protests risked being overlooked:

The hurt and outrage felt by Muslims at the blasphemous cartoons published in European countries is in danger of being pushed into the background by the wave of destruction that has engulfed us; justified protests, made legally and peacefully, and in concert by Muslim countries, will lose force. The image now in vogue of Muslim societies as volatile and excitable will be reinforced. [...] Governments in Muslim countries seeking to sponsor or participate in the anti-blasphemy demonstration should be careful: in their effort to take the sting out of the fundamentalists' frenzy or to prove themselves more Muslim than the latter, they might only be weakening their own position.

(Dawn editorial, 16.2.2006)

This editorial explicitly states that the fundamentalist forces in Pakistan may have everything to gain by the continued protests, and thus voices its liberal fear of such a development. The context is the declaration of new plans for protest demonstrations in the weeks to come. The paper further asks whether the riots may scare foreign investors away and admits that riots turning violent may also make Western governments "realize that the cartoons [...] have handed Muslim extremists with a new issue on a platter" (op.cit.). The editorial presupposes a shared "hurt and outrage" by all Muslims faced with the cartoons. But while it is certainly the case for a majority of Muslims, there may also be exceptions to the rule.

In the end, the editorial also admits that the protests against the caricatures have been used for other issues (amply shown by demonstrators burning effigies of Danish Prime Minister Anders Fogh Rasmussen and George W. Bush, and Danish and U.S. flags):

A fresh opportunity has been provided to give a religious turn to what is essentially a political issue - America's colonial obsession with controlling the world and its readiness to transgress all lines and borders in pursuit of its aggressive intent. Trying to prevent this needs wisdom, a sense of responsibility and courage rather than the foolhardiness of burning buildings and looting shops (Ibid).

Compared to the previous editorial from 4 February, the main advice of this text is not addressed to Europeans being insensitive to recent developments and religious feelings, but to the leaders of Pakistan as well as politically engaged groups and individuals. The perspective had shifted: The cartoons were first perceived as a bone of contention from the West, but the violent protests converted some of the anger into introspection and internal blame.

The more conservative The Nation seems to have a more ambiguous approach. In its first editorial after the clashes, the paper defends the Muslims' right to be "agitated and express their anger", while simultaneously blaming the authorities for the unruliness which lead to burning, looting and the killing of two men. (The Nation 15. Febru- 
ary 2006, Delicate handling). A few days later the editorials express concern of the violence and advocate more peaceful reactions (17. February 2006: Writing on the wall). Still the main blame is addressed to the authorities: "Indiscriminate arrests are likely to add fuel to the fire instead of improving the situation." (19. February 2006: How not to handle protests).

The editor of Daily Times characterises the situation in the streets of Lahore (where the paper's headquarters are situated) as "mob rule" and furthermore focuses at Pakistan's image problem:

The destruction was seen on TV by the rest of the country and the world at large. School and college boys had entered the streets with clubs in their hands. It was obvious that the march was planned to be violent. The way they set about breaking the cars and then setting fire to them was no spontaneous response to provocation. [...] Intelligence sources told Daily Times that the chain of violent incidents was orchestrated by a group of trained young activists of religious organisations.(Daily Times, editorial,16. February 2006)

Since the whole world now witnessed street hooligans changing the protest to looting and burning, the shame of the situation was underlined The editorial voices worry over businesses losing profits: "This destruction will hurt Pakistan's economy." (Lahore shops were deprived of special custom from thousands of Indian visitors who had to remain locked up in their hotels.)

The editorial in large parts narrates what went on during the "day of shame". The bitterness toward religious parties who exploited the situation and did not prevent the mob from going wild, is emphasised by the way certain religious institutions are presented: ..."after the provincial government allowed the "ulema" of 22 organisations $[\ldots]$ to stage a protest march in Lahore against Denmark in particular and Europe and the West in general". Ulema is a concept used for an assembly of religiously learned people, but Daily Times clearly does not want to recognise any of the rallying groups as being part of a real ulema. The editorial concludes using a universal analogy:

In their attempt to be holier than the mullahs, the Chaudrys of Gujrat have lost their bearings. It is time General Musharraf knocked some sense into them. This sort of nonsense cannot be allowed to continue to hurt the nation-state (Ibid).

Here is a parallel to the European idiom "more Catholic than the Pope" in the shape of accusing the authorities who should have provided law and order but instead seemed to yield their power to the extremists. In addition, the appeal to the country's unelected dictator is somewhat surprising from a paper normally adherent to critical and democratic ideals, but may be interpreted as a "lesser of two evils"-philosophy.

Jang's editorial view is expressed in the headline: "Protests should be discontinued after newspaper's [Jyllands-Posten] apology", and shows concern about the violence with a dual perspective, stating that "freedom of expression and journalism" has lead to various instances where Muslims have become the target (Jang 21. February 2006). 
In this period of aftermath, there seems to be more room for reflection, but religious parties tried to keep the issue hot (according to several columnists: for their own benefit), while others gradually lose interest. Now the protests against the cartoons were increasingly merged with other issues, for example protests against the coming visit of George W. Bush (3. March 2006) to Pakistan and the soaring food prices. In other words, the anger was still there, but now more distinctly diversified.

In Austria, British controversial historian David Irving was sentenced to three years imprisonment for speeches he made in 1989 denying the authenticity of the Holocaust. Pakistani media covered this issue broadly, and this coverage was often linked to the caricature issue.

One of the regular commentators for Nawa-e-Waqt, Qazi Mustafa Kamil, calls the Western defence of freedom of expression "false" by referring to David Irving's lack of freedom to air his views or to insult Jews (28 February.2006).

The Nation in its editorial on this issue also highlights what it considers to be European double standards and states that in spite of David Irving having expressed his regrets, he is still sentenced.

Mr. Irving's sentence comes at a time when the West is dishing out the popular theory of freedom of expression to the Muslim World in support of publishing blasphemous cartoons. This lays bare the hypocrisy lying at the very roots of Western ideology. [...]It goes without saying that the intensity of the blasphemous cartoons is much more on religious grounds compared to the ethnic context of the Holocaust. Still the West makes it an issue of freedom of expression. (The Nation, editorial, 22. February.2006)

This is a rather unique example of characterising the right to freedom of expression as a "popular theory", but may be interpreted as sarcasm linked to the way in which Irving in practice is denied this right.

Dawn points to the European countries "aggressively defending the right to freedom of speech" and concludes that the sentencing of David Irving is "bound to open a debate on Western double standards" (22. February 2006). The editorial reminds readers that the cartoons were defended by both editors and the European Union itself "which attaches a great deal of importance to the freedom of expression but criminalizes any denial of the Holocaust." (op.cit.). Furthermore, the editorial states:

If Europe is sincere about defending its societies' right to freedom of speech, it must also concede the right to question the veracity of historical experiences, however uncomfortable it may make society feel in some cases. The Holocaust was a tragic event but any study or analysis of it cannot be hampered by laws that do not allow an honest exploration of the events surrounding it. [...] If the Muslim world has to learn to respect ideals that go against its beliefs and convictions, the same must be true of Europeans. People must be allowed to hear all views and come to their own conclusions. (Dawn, editorial, 23. February.2006)

In the above text a presupposition is embedded: that David Irving may be viewed as an "honest explorer" of the Holocaust events, and that more exploration into this history 
is needed, even if "uncomfortable". The Holocaust itself is euphemistically characterised as a "tragic event".

Daily Times addresses the same issue two days later, and the editorial starts very distinctly by declaring that "Free Europe is not so free after all". It then gives an outline of David Irving's sentence and the law he was violating. The text also compares Irving to other academics who have been disgraced for plagiarism or faking research, plus athletes caught using drugs: "But none has ever gone to jail. The disgrace itself is enough." The editor questions the fairness of jailing Irving for his views, "even if he is wrong".

Furthermore, his sentence could not have come at a more unpropitious time, just as Europe is raising the flag of "free speech" to justify the publication of grossly offensive caricatures of Prophet Muhammad [...] If free speech indeed means no holds barred, then Mr Irving should be a free man. That he is not makes it important to put the cartoon affair in the proper context. [...] Europe cannot afford to go back to its anti-Semitic past whose name still stands out in the existence of the word pogrom. All this is fine. But why can we not apply the same benchmark to other sensitivities involving over a billion people? If it is clear that some people - forget the Muslims - revere their prophet, should others be allowed to make fun of their beliefs, especially if it can be proved - and is clear - that such an action is based on racism and double standards? (Daily Times, editorial, 25. February.2006)

The editorial recommends universalist thinking by the excerpt "forget the Muslims", implying that this controversy is more about decency toward religious people in general. It is also, more explicitly than Dawn, in line with the "European" view on Holocaust, demonstrating knowledge about how the history of anti-Semitism paved the way for Nazism. But the double standards discourse seems to be the most prominent: where to draw the line when it comes to insulting other people's feelings and beliefs? Should the threshold for freedom of speech be lower when it comes to Muslims than insulting Jews?

Again "Europe" is treated as an entity, in the same way as European media often treat "Africa" (more seldom Asia, more often Muslims) as an entity, a country of sorts, thus depriving the continent its variety of nations, cultures, religions and points of view.

\section{The monthlies}

Due to practical reasons (routines \& schedules) the magazines Herald and Newsline covered the cartoon controversy only in the third phase, both in their March issues. Their coverage differs substantially from the daily newspapers, by being more lenient towards a "Western" perspective. Since the readership of these is even smaller than in the case of the English language newspapers, it is likely that the editors and writers can afford a larger degree of liberality. 
Nadir Hassan in a three page comment in Herald $^{24}$ tries to explain the motives of Jyllands-Posten's publication, by stating that the caricatures were created

... not in a void, but in response to the very real climate of fear created by Islam in Europe. [...] The cartoonists' fears seem well grounded on a continent where the Dutch film-maker Theo van Gogh was stabbed to death by a radical Muslim and Dutch politicians, including the Somali-born Ayaan Hirsi Ali, who has converted from Islam to Christianity and spoken out against the treatment of Muslim women, must live in protective confinement. Such examples seem to justify Rose's original concern that Europe's hard-fought freedom of expression is now at stake. (Nadir Hassan, Herald, March 2006)

This columnist furthermore considers the radical Islamists as a threat to European freedom of expression, the "real controversy here is not that the Europeans hate Islam but that the continent has taken secularism so far that any public acknowledgement of religion is considered a threat to liberty" (op.cit.).

In this comment, "Europe" is again largely treated as an entity, and so is "Islam" on that continent, supported by a few extreme examples. The writer also challenges the views of Tony Blair and other leaders who claim that "free speech does not include the right to offend one's own or another's faith". According to him this argument

... fails to note that freedom of speech, if it has any purpose at all, exists to protect unpopular political speech. By printing the cartoons, Jyllands-Posten has exposed the violence of radical Islamists and highlighted Europe's increasing willingness to curtail certain freedoms. [...] Without the right to offend, the world would be bereft of important satirical and dissenting voices. [...] A little over a decade ago, British author Anthony Burgess wrote an epic poem Byrne in which a European Union conference is bombed by Muslim extremists offended by a statue of the antiMuslim poet Dante. With radical Islamists winning the battle over their right to censor the media and European governments serving as their enablers, Burgess' dystopian nightmare seems to have come to pass (Ibid).

These expressions made by the one comment highlighted in the March issue, demonstrates the willingness of Herald to challenge a rather massive consensus in Pakistan of freedom of expression being accepted as limited by certain sensitivities. In addition, the writer highlights his own (Western) cultural capital in the punchline by quoting a famous author - and by possessing detailed knowledge of European events. This text is the most "secularised" and "understanding-of-presumed-European-values" in the sample.

Newsline 25 invited the Director General of the Human Rights Commission (HRCP) in Pakistan to deliver the comment which, as in Herald, is placed after the cover story. I. A. Rehman states that the events "constitute one of those exceptional cases when something can be said for all the parties involved and much more can be said against

24 "Crossing the line", Herald, March 2006.

25 Newsline was the magazine that covered the story of "Reconciliation in Oslo", in which it is exposed that "Norwegian-Pakistanis played a key role in defusing a potentially explosive situation in Norway.". 
them." This very first paragraph of the comment signals a "balanced" approach. ${ }^{26}$ Rehman then moves on to (one of) the cartoonists:

Whatever the provocation, he stumbled into a grave error when he apparently tried to trace the roots of terrorism in the Islamic belief. Muslims have only recently joined the roll of terrorists. Those senior to them belonged to other religious denominations, while some claimed to be nonbelievers. Their actions were not attributed to the founders of their faiths. The singling out of Muslim faith for the authorship of terrorism amounted to a dangerous provocation. (I.A. Rehman, Newsline March 2006)

The magazine's selection of commentator is important, as the Human Rights Commission is associated with the defence of freedom of expression in a large number of cases. Besides, Rehman, a seasoned editor and journalist, is associated with professional authority. Rehman disagrees with "some Muslim groups" who have demanded new laws to prevent attacks on sacred personages, since "the human rights code already bars attacks on founders of religions and the beliefs of various communities". He also refers to several other conventions, among them the European convention of Human Rights.

However, what is involved here is not a point of law but a matter of culture. The Christian societies of Europe have developed their culture of free debate to such an extent that writers and filmmakers can discuss Christianity and Jesus Christ in any manner without angering their majorities or hurting their feelings. Colonial bondage over long decades denied large populations of Asia and Africa, and they include the whole of the Muslim world, the possibilities of developing traditions of free discourse, and of tolerance for dissent. [...] The Muslims, in south Asia specially, have been forced to fall back on what Iqbal called the defence mechanism of dogma by suffering denial of their political and economic rights for centuries. They will not be helped to overcome their intellectual and cultural lag by being offensively reminded day in and day out of their inadequacies (ibid).

In this comment the development discourse is embedded, but here there is no "blaming the victim" (Shohat and Stam 2004: 57), rather an account of the effects of colonialism generating the "intellectual and cultural lag" and appeals more strongly to the audience by referring to Iqbal, ${ }^{27}$ a revered person in Pakistan's history. Continuing, Rehman's tone turns harsher:

All restrictions on the freedom of expression as well as on academic and artistic freedom are bad and can never be accepted as anything more than a necessary evil justifiable in consideration of the shortcomings found among a community's children or its grown-ups who display underdeveloped minds or mindsets that are not amenable to reason (ibid).

26 The lead, placed inside a picture most likely from the riots in Lahore Feb 14th, underlines such an approach: "The arguments advanced by opposing sides of the cartoon controversy are far from convincing.".

27 Muhammad Iqbāl (1877 - 1938) was an Indian Muslim poet, philosopher and politician, known as the first man to propose the idea of an independent state for Indian Muslims, thus inspiring the creation of Pakistan. He worked closely with Pakistan's first leader Mohammad Ali Jinnah, and is referred to as Allama (scholar) Iqbal. 
This passage might be read as an adapted Orientalist expression, representing the Other as child-like and thus inferior, and in addition adhering to the binary opposite of (Western) reason against (Eastern) emotion. However, when simultaneously leaning to the "theory of unequal development", ${ }^{28}$ the comment may be interpreted as less hostile to the minds "not amenable to reason".

The dilemma of this commentator is obvious: On the one hand, he displays an antiimperialist attitude and thus remains critical of the West (and the caricatures); on the other he wants to signal his distance to politico-religious obscurantism and - not unlike other commentators - will not let his own leaders remain protected from critique of double standards:

...Pakistanis have entered the fray with unclean hands. A state that permits discrimination on the basis of belief, and that too by constitution and by law, and gloats over it, is not entitled to protest against such discrimination by others, whether real or imagined. We have to put our own house in order before we can set out to teach others justice and fair play. (ibid)

By this 'self-reflexive' passage, referring to universal popular words of wisdom, Rehman seems to issue a warning directed at the more 'superior' attitude of some editorials and columnists, who in their texts have tended to "teach the Europeans" a lesson of sensibility.

\section{Variety and simplification}

In its first phase, the cartoon controversy seemed to create a Pakistani national consensus. The overall characterisation of the cartoons in the national newspapers examined remained negative; the most frequently used characteristics being "blasphemous", "provocative" and "sacrilegious", while a similar consensus seemed to prevail when it came to the limits of freedom of expression: symbolised by expressions like "with responsibility" or "sensibility" when it came to suggesting how this freedom should be practised. Thus traditional national adversaries (liberal-progressives and conservative Islamists) partly reached a temporarily unified point of view on "the general situation" concerning the cartoons, seeing them as a Western provocation and revealing a lack of sensitivity for the feelings of the Muslim Ummah. This may be summarised as the discourse of disgust, accompanied by the discourse of sensitivity.

Besides, two other discourses may be observed. One is the exposure of double standards in the West, by editorials and columnists mentioning both David Irving, who has been sentenced for his views on the Holocaust, and Jyllands-Posten's previous refusal to print some cartoons of Jesus Christ. ${ }^{29}$ Yet another observation is that columnists in some English language papers conduct in-depth research and quote from the constitutions of, for example, Norway and France (see above) or the Danish penal

28 Also called Dependencia theory (Samir Amin, Andre Gunder Frank etc).

29 Since Jesus is considered one of the Prophets of Islam, mocking or caricaturing him is considered equally harmful as the caricatures of Prophet Mohammed by many writers in Pakistan. 
code ${ }^{30}$ thus demonstrating both a willingness to understand how the Europeans operate (global consciousness) - and appealing to what is considered "dormant" paragraphs on blasphemy in mainstream Europe.

In their coverage the English language papers, to a degree, gave space to Danish media players and politicians, as both the cultural editor and the editor-in-chief of Jyllands-Posten have been allowed space to explain their views, as well as Danish Prime Minister Anders Fogh Rasmussen, other Danish politicians and scholars, and other Western commentators. James Carrier's wisdom of representation of the Other often implying a simplified representation of the (Occidental) "we", may be observed adversely in these editorials, in the sense that "Muslims" are largely treated as an entity with a certain (wounded or offended) attitude to the cartoon controversy. This corresponds also with Buruma and Margalit's approach of the Occidentalism as a response to humiliation. But although it may hold true that "most Muslims" in Pakistan and many other countries were offended by the cartoons (helped by the media coverage), it is equally true that "most Muslims" never saw them and they were not - or poorly informed of the initially expressed intention of the publication, linked to a certain understanding of relations between Diaspora and the majorities of their country of settlement. And as shown especially from the monthlies, not all were equally offended.

In the texts, other general categories like "Europe" and "The West" are also frequently applied - as they are indeed in Western media. But categories are interpreted differently. "Europe" is represented both as backward - not understanding how the world is developing into more complex societies also 'at home' - and advanced, as in the continent's rapid move towards secularism. Thus two varieties of the development discourse are demonstrated. In several texts, there are hints at conspiracy theories, that is, seeing the cartoons as part of a larger attack on the Muslim world.

The overall impression is that the English dailies are more liberal and, to a certain extent, accommodating when it comes to representing "European" ways of thinking than the Urdu newspapers, and that the English language monthlies are more liberal (and in one instance even supportive of the Jyllands-Posten position) in their approach than the dailies.

The importance of the Diaspora is highlighted in several ways: in the monthlies (and some comments in the dailies) by mentioning the way some Muslim clerics from Denmark contributed to the spreading of the protests against the caricatures and thus to ignite the general uproar more than four months after the initial publication. Secondly, the Diaspora is referred to when 'appealing' to European general opinion to take the feelings of the Muslim population in their countries more into consideration. Could this also be seen as an appeal to traditional European citizens to adapt to an important aspect of post-colonial modernity?

In the demonstrations against the caricatures several issues were merged, like the forthcoming visit of President George W. Bush and the soaring food prices. This was also reflected in the newspapers, especially in the last phase of intensive coverage. The 
merging may have been universal, varying with the level of general discontent in the respective countries.

The differing voices, the nuances and the self-reflexiveness seen in the aforementioned editorials and comments, reveals a picture of a Muslim nation somewhat unlike the 'European' news coverage representations of a country like Pakistan. Often, the coverage concentrates on aggressiveness and rage, and thus gives more credit to the parties with 'street power' than they may quantitatively deserve. Thus also, to use Fairclough's terms, other protests and other voices may be backgrounded or absent (Fairclough 1995,106), and a more bipolar picture occurs.

The diverse voices and points of view emerging especially in the aftermath of the controversy's first phases, also demonstrate that there is indeed a struggle going on in the journalistic field in Pakistan, a struggle influenced both by the religious-political field 'at home' and by discourses in European media. Although this struggle may be registered only by an elite due to the character of the publications analysed, the elite certainly consists of 'decisive intellectuals' and people in powerful positions, and thus the coverage examined may have had a larger impact than a limited audience would indicate.

\section{References:}

Ali, Tariq. 2002. The Clash of Fundamentalisms: Crusades, Jihads and Modernity. London: Verso Benson, Rodney and Eric Neveu. 2005. Bourdieu and the Journalistic Field. Cambridge: Polity Press Bhatia, Vijay 2001.Generic Integrity in Professional Discourse. Lecture at Genre 2001. Oslo: Høgskolen i Oslo.

Bourdieu, Pierre 1998. Om fjernsynet. Oslo: Gyldendal

Buruma, Ian, and Avishai Margalit. 2004. Occidentalism. The West in the Eyes of Its Enemies. New York: The Penguin Press

Carrier, James G., ed. 1995. Occidentalism. Images of the West. Oxford: Clarendon Press

Chouliaraki, Lilie, and Norman Fairclough. 1999. Discourse in Late Modernity. Edinburgh: Edinburg University Press

Eide, Elisabeth. 2002. "Down there" and "Up here": "Europe's Others" in Norwegian Feature Stories, Doctoral thesis. Oslo: Unipub

Eide, Elisabeth. 2006. "The Empire and the Egyptians". In Special Issue of Nordicom. 2/2006: 153-169

Eide, Elisabeth \& Simonsen, Anne Hege (2008): Verden skapes hjemmefra. Oslo: Unipub

Eide, Elisabeth, Kunelius, Risto \& Phillips, Angela (eds. 2008): Transnational Media Events. The Mohammed Cartoons and the Imagined Clash of Civilizations. Gothenburg: Nordicom

Eide, Elisabeth \& Simonsen Anne Hege (eds. 2009): Dekke verden. Lærebok i utenriksjournalistikk. Kristiansand: IJ-forlaget

Fairclough, Norman.1995. Media Discourse. London: Arnold

Forte, David. 1994. “Apostacy and Blasphemy in Pakistan”. In Connecticut Journal of International Law, Fall 1994:

Galtung, Johan. 2002. “USA, Vesten og “Resten” etter 11. september og 7. oktober 2001”. In Krigens retorikk, Elisabeth Eide and Rune Ottosen. Oslo: Cappelen 
Gewertz, Deborah, and Frederick Errington. 1991. "We think, therefore they are? On occidentalizing the world". In Anthropological Quarterly, Vol 64, Issue 2: 80-96

Hall, Stuart. 1992. "The West and the Rest: Discourse and Power". In Formations of Modernity, ed.

Bram Grieben and Stuart Hall. Cambridge: Polity Press

Hjarvard, Stig, ed. 2001. News in a Globalized Society. Göteborg: Nordicom

Human Rights Commission of Pakistan. 2006. State of Human Rights in 2005. Lahore: HRCP

Orient McCann Erickson. 2005. Orient Blue Book 2005, Karachi

Said, Edward W. 1995. [1978]. Orientalism. London: Penguin

-. 1981. Covering Islam. London: Routledge \& Kegan Paul

-. 1994. Culture and Imperialism. London: Vintage

Sardar, Ziauddin. 2004. "Why do they hate us?” In New Statesman October 4, 2004. http://www.newstatesman.com/200410040042

Shohat, Ella, and Robert Stam. 1994. Unthinking Eurocentrism, London: Routledge

South Asian Free Media Association. Pakistan. 2004. Amending Media Laws. Lahore: SAFMA

\section{Appendix 1:}

The publications

\begin{tabular}{|l|l|}
\hline PUBLICATION & CHARACTERISTICS \\
\hline Dawn & $\begin{array}{l}\text { English language. Founded by the first leader of in- } \\
\text { dependent Pakistan, Mhd Ali Jinnah in 1947. Tradi- } \\
\text { tional-liberal Elite oriented. Main office in Karachi. } \\
\text { Largest in circulation of the English language papers }\end{array}$ \\
\hline The News & $\begin{array}{l}\text { English language, founded in the early 1990s, the se- } \\
\text { cond largest English language newspaper. Considered } \\
\text { liberal. Linked to Urdu daily Jang (same newspaper } \\
\text { group, same main office in Lahore) }\end{array}$ \\
\hline The Nation & $\begin{array}{l}\text { English language newspaper, considered more con- } \\
\text { servative than the above. Linked to the Urdu Nawa-e- } \\
\text { Waqt }\end{array}$ \\
\hline Daily Times & $\begin{array}{l}\text { English language. Newcomer, radical-liberal. Head- } \\
\text { quarters in Lahore. Very elite oriented. Small circu- } \\
\text { lation }\end{array}$ \\
\hline Jang & $\begin{array}{l}\text { Urdu language. Headquarters in Lahore, largest na- } \\
\text { tional newspaper. Linked to English daily The News. }\end{array}$ \\
\hline Nawa-e-waqt & $\begin{array}{l}\text { Urdu language. Headquarters in Lahore, founded in } \\
\text { 1940. Conservative. Linked to English daily Nation. }\end{array}$ \\
\hline Herald (magazine) & $\begin{array}{l}\text { English Language monthly, belongs to the Dawn } \\
\text { group, published from Karachi. Widely read abroad, } \\
\text { largest English current affairs magazine in Pakistan }\end{array}$ \\
\hline Newsline (magazine) & $\begin{array}{l}\text { English Language monthly, published from Karachi. } \\
\text { Critical: "born of a dedicated band of journalists' re- } \\
\text { fusal to toe the line". }\end{array}$ \\
\hline
\end{tabular}




\section{Chapter Thirteen: \\ The Cold war Triumph of Radio Free Europe}

\section{Arch Puddington}

Radio Free Europe (RFE) was arguably America's most successful venture in what has come to be known as public diplomacy and among America's most notable nonmilitary initiatives during the Cold War. RFE went on the air in 1950, beaming a prodemocracy, anti-Communist message to five of Eastern Europe's Soviet satellite states: Poland, Czechoslovakia, Hungary, Romania and Bulgaria. (It later added the services beamed to the three Baltic republics). For nearly two decades, the station was covertly funded by the Central Intelligence Agency, as was America's other "freedom radio," Radio Liberty, which broadcast a similar message to the Soviet Union in both Russian and the languages of the non-Russian peoples.

In its heyday, RFE boasted a huge listenership throughout the satellite bloc. Poles regarded RFE with reverence; the station played an important role in bringing down at least three party leaders and was instrumental in sustaining the trade union Solidarity when it was forced underground by martial law. During Nicolae Ceausescu's time, RFE was Romania's most popular source of news. Ceausescu responded with fury; he dispatched hit squads to assassinate RFE journalists and hired the international terrorist Carlos the Jackal to bomb the station's Munich headquarters. The émigré writer Georgi Markov was murdered in the infamous umbrella assassination incident on direct orders of Bulgaria's party chief, Todor Zhivkov, because of broadcasts over RFE that touched on Zhivkov's personal life.

Radio Free Europe derived much of its credibility from the popularity of its commentators: men who, had they lived in normal societies, would have been the editors, columnists, and news anchors of a free press. When Ceausescu dispatched his thugs to kill or maim RFE journalists, he chose as his targets those who were the most beloved by the Romanian people. Each of RFE's services could place before the microphone commentators who had the rare ability to give quiet inspiration to oppressed people without polemics, pontification, or condescension.

The station's appeal was strengthened further by its diligence in reporting facts that the Communist authorities either distorted or ignored. This was a major challenge due to Communism's ability to seal off practically all sources of accurate information. RFE thus hired a team of researchers who specialized in ferreting out whatever information was available and then providing the broadcast services with reasonably reliable information to counter whatever fabricated success stories filled the regime press.

Although everyone understood that RFE was an American project, it consciously cultivated the image of a European radio station. Its broadcasts did not emphasize American popular culture, and when it pointed to examples of Free World achievement, 